\title{
The Change of Manggaraian Clothing: A Historical and Semiotic Study
}

\author{
Ans Prawati Yuliantari ${ }^{1}$, Yuliana Jetia Moon ${ }^{2}$, Priska Filomena $\mathrm{Iku}^{3}$ \\ Universitas Katolik Indonesia Santu Paulus Ruteng ${ }^{123}$ \\ \{tia.yuliantari@gmail.com\}
}

\begin{abstract}
One element of culture which owned by society as identity is traditional clothes. It has significant philosophical values. The phenomenon, then, raises questions to be investigated: how are the transformation forms of Manggaraian traditional clothing? Why there has been a change in Manggaraian traditional clothes? To answer those questions, a semiotic approach proposed by Saussure and then developed by Barthes has been used by the researchers. This research is a library research which is categorized as qualitative research. The method used in this research was thick description proposed by Pontoretto. Data collection were done by observation, literature study, and interviews. The result of the study shows that Manggaraian traditional costumes has been changing throughout decades. The biggest impact comes from South Sulawesi because Manggarai was under control of Gowa Kingdom until the Dutch dominated Flores island. Nevertheless, there is an adjustment with the surrounding condition namely the use of local motifs as the manifestation of Manggaraian natural condition.
\end{abstract}

Keywords: Culture, clothes, Semiotics, Culture, Manggarai

\section{Introduction}

Manggaraian people expresses their identity through their culture, both physically and nonphysically. The form of physical culture such as house, traditional equipment or other daily equipment, musical instrument and traditional clothes are changing through decades; however, the non-physical cultural products as oral literature, traditional ceremonies, songs, dances, and the philosophy as the role model of society remained long lasting in the Manggaraian society. One cultural element which is owned by society as their identity is traditional clothes (Koentjaraningrat, 2000)1. As the part of culture, traditional clothes have important philosophical values. The traditional clothes which are worn in certain rituals do not only function as a decoration or formality of an event, but also are arranged based on thoughtful and cultural experience of the society. The symbols of those traditional clothes cannot be changed or modified without considering the standard rules.

The traditional cloth for Manggaraian woman is known as mbero. It refers to a type of blouse which is worn at the top and songke which is like a sarong as its undershirt. As a headdress is balibelo which is wrapped around the forehead in formal ceremony, in non-formal ceremony Manggaraian woman wears a blouse and songke. The characteristics of Manggaraian woman traditional clothes has been changed. Woman's traditional cloth which is recognized by convention is mbero, however nowadays, most of Manggraian woman wear songke and various models of kebaya. This phenomenon raises two questions: what is the transformation form of Manggaraian traditional custom? Why does the changing occur? 
Koentjaraningrat (2000)1 mentioned that the products of culture consist of basic form, social system and physical cultural product. The basic form includes norm, value and philosophy point of view which take time to change, while the social system plays as the reflection of those basic form, as well as cultural products like things. The physical cultural products are buildings, daily tools or equipment and cloths. Cloths in a society do not only over the body but also as the reflection of ideas and symbols of its community. It also presents the personal taste of the wearer.

The role of cloth in this system illustrates the semiology pattern proposed by Saussure which is developed by Barthes (2013) 2 in which the cloths are represented as the text. Saussure mentions that language consists of langue which means different system in sign and parole, which refers to individual style to speak (Coble \& Jansz, 1997)3. Langue is the collection of signs which sometimes can be used to form parole, "Langue is the social institution, independent of the individual; it is a normative reserve from which the individual draws their parole, 'a virtual system that is actualized only in and through parole'. Parole is the individual act, 'an actualized manifestation of the function of langage', langage being a generic term for both langue and parole." (Barthes, 2013, p. 8).

The analogy proposed by Saussure is taken by Barthes in analysing cloth. According to Barthes, the word cloth is synonym to langue, which means something that is detached from an individual personality, a normative system and directly connect to the social system of a society. Instead, cloth refers to an individual reality, way of dressing, where an individual actively uses her body to wear the cloths of her choice. Besides using the concept of langue and parole, Saussure also uses the concept of signifier and signified (Ahimsa-Putra, 2006)4. Signifier is the material aspects of language, while signified is the mental aspect. In concept of fashion, "The garment is always conceived, implicitly, as the particular signifier of a general signified that is exterior to it (epoch, country, social class)" (Barthes, 2013, p. 12). Dress, actually, is not more than signifier of a main signified that is the way or level of wearer participation, both individually and group. In specific condition, the influence of internal and external factors and convention among the wearer itself can cause change in terms of form, pattern and time of wearing.

The development of technology information and infrastructure leads to the distribution of goods and services smoother year by year. According to Webb (1994)5, several years after the New Order there was the construction of facilities and infrastructure to facilitate communication and transformation with other regions. It encourages the Manggaraian people to be acquainted to cultures from outside. The opening of cultural barriers due to technological improvement led to the presence of other cultural influence (from outside) which enters Manggarai region. The characteristics of Manggaraian woman traditional clothes has been changed. Woman's traditional cloth which is recognized by convention is mbero, however nowadays, most of Manggraian woman wear songke and various models of kebaya. This phenomenon raises two questions: what is the transformation form of Manggaraian traditional custom? Why does the changing occur?

By doing this research, other researchers who are interested in Manggarain traditional clothes may use this research as a reference. This research also attracts youth enthusiasm and Manggarain people to wear their cloths in various ceremonies. 


\section{Research Methods}

This research is a library research which is categorized as qualitative research. The method used in this research was thick description proposed by Pontoretto (2006)16, which is analyzing phenomena by describing and interpreting the text content contextually and providing understanding for readers. Data collection were done by observation, literature study, and interviews. Thus, the characteristics of this research are the study of photo and picture of Manggaraian traditional cloth of different periods in some books and internets sources which is counted based on year determined by the researchers. Trough those pictures, symbols of Manggaraian traditional cloth, both original and modified can be found. That point are described and studied comprehensively to find its contextual meaning.

\section{Results and Discussion}

The cloth worn by the women in the 18th century is plain woven cloth, woven fabric with sui motif, and tetoron. The woven cloth indicated that Manggaraian people had produced their own fabric. The basic material of the fabric is yarn produced from cotton. Manggaraian people had planted their own cotton. The Dutch had dominated Manggarai since 1907. The tetoron is a fabric produced by factory. So, the Manggaraian people took part in trading with other regions. Manggaraian women cloth is similar to Bodo cloth from Makassar. The influence of Makassar is seen as the development of cloth worn by Manggaraian women which only covered her upper body by tying the cloth to the chest or tied to the shoulders.

Based on the picture of Caci dancers in 1915, it is concluded that Manggaraian people had skill to produce their own fabric. It is proved by the man in the right side who worn plain black fabric and the shawl worn by the dancer in left side. The picture also shows, there was batik pants and batik headgear as the special fabric from Java. However, in Manggaraian history (Toda, 1999)21, Java did not have direct connection to Manggarai region. The impact comes from Gowa situated in Makassar as the centre trading of eastern, western and southern (Nur et.all 2016).

Traditional cloth of South Sulawesi is more visible on the cloth of authorities, influenced by South Sulawesi toward the district chief namely Dalu in Manggaraian people. The impact occurred in 17th-19th century since the region was under the control of Gowa Kingdom (Toda 1999)21. Wearing Makassar cloth indicated the power of superior, in this case Gowa Kingdom in South Sulawesi.

The influence of Gowa is also portrayed from clothes worn by men. The clothes are in woven fabric with gold yarn patterned. The used clothing mode is a koko shirt with a standing collar and the undershirt is long pants. The fabric used for this suit is silk, a textile product not manufactured in Manggarai. Besides, Manggaraian men just wear sarong as their daily cloth, not long pants. Based on the cloth pattern, it is concluded that the costume worn by the Cibal tribe was gotten through trading.

The oldest picture with a Manggaraian woman worn a balibelo was gotten in 1939. Iku's research (2017)22 explained a balibelo is a result of Manggaraian cultural transformation Karong Woja Wole. In this cultural ceremony, traditional leaders wounded plants around their head. This Manggaraian woman also worn an ivory bracelet. It is assumed that the ivory bracelet 
met Manggarai due to trading with East Flores. This assumption is based on the habit in East Flores which use the ivory as dowry in traditional ceremonies.

Triyanto (2010)23 mentions that kebaya came into Indonesia since 15th-16th centuries. It is assumed that kebaya entered Manggarai without direct trading with Java, but through trading with Makassar. The picture above shows two Manggaraian dancers performed traditional dance. Unlike the picture taken in 1900 s, where the dancers wore bodo shirt, the picture shows the dancers wore bright colored kebaya. It indicates that in 1939, there was a changing in Manggaraian women cloth pattern, especially the pattern of blouse as the pair of sarongs.

\section{Conclusion}

Manggaraian traditional cloth has been changed from time to time. The changing happens due to the connection to the outsiders who bring new technology to the region. That technology is neither new material in fabric and fashion nor the yarn spinning methods as proves that Manggaraian people can produce clothes. In its progress, men's and women's traditional has been hanging. The biggest impact comes from South Sulawesi because Manggarai was under control of Gowa Kingdom until the Dutch dominated Flores island. Nevertheless, there is an adjustment with the surrounding condition namely the use of local motifs as the manifestation of Manggaraian natural condition.

\section{References}

[1] Koentjaraningrat. (2000).Pengantar Ilmu Antropologi. Jakarta: Rineke Cipta

[2] Barthes, R. (1990). The Fashion System. Los Angeles: University of California Press.

[3] Coble, P., \& Janzs, L. (1997). Introducing Semiotic. New York: Totem Book.

[4] Ahimsa-Putra, H. S. (2006). Strukturalisme Levi-Strauss: Mitos dan Karya Sastra. Yogyakarta: Kepel Press.

[5] Arnold, R. (2001). Fashion, Desire And Anxiety: Image And Morality In The 20th Century. New York: IB Tauris.

[6] Lukman, C. C., Piliang, Y. A., \& Sunarto, P. (2013). Kebaya Encim as the Phenomenon of Mimicry in East Indies Dutch Colonial's Culture. Arts and Design Studies Vol.13, 2013, 15-22.

[7] Karyaningsih, E. W. (2015). Faktor-Faktor Yang Mempengaruhi Pemilihan Kebaya: Pada Ibu-Ibu Dan Remaja Putri. Jurnal KELUARGA Vol 1 No 1 Februari 2015, 7-13.

[8] Cantony, V. (2005). Behind "Through the Kebaya. Artery, vol 1 Issue1, May,, 12-13.

[9] Indonesia, D. P. (2008a). Batik in Indonesia, Jakarta: Departemen Perdagangan Republik Indonesia.

[10] Langi, K.-C., \& Park, S. (2017). An Analysis of the Characteristics of Balinese Costume:: Focus on the Legong Dance Costume. Journal of the Korean Society of Costume, 38-57.

[11] Crane, D., \& Bovone, L. (2006). Approaches to material culture: The sociology of fashion and clothing. Poetics 34 (2006), 319-333.

[12] Skov, L., \& Melchior, M. R. (2008). Research Approaches to the Study of Dress and Fashion. Copenhagen: Copenhagen Business School

[13] Erb, M. (1999). The Manggaraians: A Guide to Traditional Lifestyles. Kualalumpur: Time Edition.

[14] Allerton, C. (2007). The secret life of sarongs : Manggarai textiles as super-skins. Journal of Material Culture 12 (1), 22-46

[15] Pontoretto, J. G. (2006). Brief Note on the Origins, Evolution, and Meaning of the "Thick Description". The Qualitative Report Vol. 11 No.3 September 2006, 538-549.

[16] Erb. Meribeth. 1997. Constructions of History in Todo, Manggarai (Western Flores, Indonesia) Journal of South is Asian Studies. Vol. 28 No. 1. Hlm 47-77 
[17] Nahdia Nur, Bambang Purwanto, dan Djoko Suryo. Perdagangan dan Ekonomi di Sulawesi Selatan, pada Tahun 1900-an Sampai Dengan 1930-an. Jurnal Ilmu Budaya Vol. 4 No.1 Hlm. 617-712

[18] Sahid dan wahyuni. 2001. Keragaan dan Konsep Perbaikan Pengembangan kapas di Indonesia. Monograf Balittas No 7. Malang: Balai Penelitian Tanaman Tembakau dan Serat

[19] Steenbrink, Karel. 2013. Dutch Colonial Containment Of Islam In Manggarai, West-Flores, In Favour Of Catholicism, 1907-1942. Bijdragen Tot De Taal-, Land- En Volkenkunde 169 (2013) 104128

[20] Toda, Dami. 1999. Manggarai Mencari Pencerahan Histografi. Ende: Nusa Indah

[21] Iku, Priska Filomena. 2017. Kazanah Lingual Kepadian pada Masyarakat Tutur Manggarai (Kajian Ekolinguistik). Semarang:Unes

[22] Triyanto 2010. Kebaya sebagai Tren Wanita Indonesia dari Masa ke masa: Yogyakarta 